\title{
Post-conflict Reconciliation in Aceh, Indonesia: Perspectives from the Victims
}

\author{
Abdul Manan', Abdul Hadi' ${ }^{2}$ Iping Rahmat Saputra ${ }^{3}$ \\ ${ }^{1}$ Universitas Islam Negeri Ar-Raniry, Banda Aceh, Indonesia (abdul.manan@ar-raniry.ac.id) \\ ${ }^{2}$ Sekolah Tinggi Agama Islam Tgk Chik Pante Kulu, Banda Aceh, Indonesia (abdul.hadi@pantekulu.co.id) \\ ${ }^{3}$ Universitas Islam Negeri Ar-Raniry, Banda Aceh, Indonesia (iping.saputra@uin.ar-raniry.ac.id)
}

\begin{abstract}
This field research using participant observation critically analyzed the post-war reconciliation between Aceh Province and the Indonesian Government. Special attention was paid to the violent incidents at Rumoh Geudong, Krueng Arakundoe, and Jambo Keupok. Besides, in-depth interviews with 16 informants who were engaged directly and indirectly on the problems to collect the data, followed by employing library research to sight the findings. The peace agreement was concluded by parties who hated each other. Contrarily, the government's function as the developer of the post-understanding process was not shown substantially. This has further enhanced the new forms of violence carried out after the previous violence. This meant nothing to the power of peace itself. The reconciliation was not substantially successful but failed. The absence of which had an impact on the existence of war victims, particularly in rebuilding their psychological conditions. Human values during the 14 years of peace were not programmed in priority at all, which generated extensive sustainable peace. The collapse of the state's responsibility to unravel all cases of dehumanization had an impact on the increasingly dominating pragmatic value, meaning that the value of the existence of war victims was minimal, even closer to nothing.
\end{abstract}

\section{Keywords}

post-conflict; reconciliation; Aceh; Indonesia; victims' perspectives

\section{Introduction}

The violent incidents that happened in Aceh Province, Indonesia, were firstly determined as the Military Operation Area (MOA) and afterward, apparently still left an unforgettable scar. The process of final conflict resolution mediated by the Crisis Management Initiative (CMI) does not necessarily present improvements in the ruins of the mental and life aspect. It is very easy to do things, which are full of rudeness and humiliation for the citizens as if they are not part of the citizens. The state is hostile and reviles with inhuman actions over the existence of the citizens themselves. Perhaps, if it still goes on, it may resemble the enmity between Arab and Israel (Lewin, 2016).

For about 20 years after the incidents, the inner hurt that pervades the lives of
Acehnese people has not yet fully recovered. The unrecovered scars, the irrelevant of whole policies done by the elite on the mandate of the 2005 Memorandum of Understanding (MoU) in Helsinki, and even the moral appreciation were mistakenly used as the form of arrogance shown by the national armies and policies.

The described circumstances are continuing today through all media and material done by the political policy, seeming that Aceh has long forgotten the past incidents. The core of the resolution of the violent incidents depends on the Indonesian Government and the local government of Aceh Province. There is an unseen statement in the MoU underlining that Aceh Province autonomously and fully takes charge as an illiberal peacemaker to solve and rebuild the civilization post-conflict. 
The devastated unfair law once again has shown a defective implementation of the MoU. Since then, the insecurity happened frequently toward an aggrieved group of people. The law has not touched the victims' souls; it just touches the surface. Law is not a drama, and the court is not the theater, which can be dramatized by the policymaker for pleasure.

The thing that is commonly ignored after the war is starting the reconciliation. Rhetorically speaking, it requires substantial faith in works but promised words of involved parties in a conflict (Doxtader, 2003). The reconciliation is not merely ordinary shaking hands with agreement mediators, yet it involves the dignity of a human. Nevertheless, reconciliation left a question mark for people involved, particularly the war victims. The flummoxed may challenge certain people to adapt to the new demographic and socioeconomic issues (Nussio et al., 2015). Bloomfield (2006) agrees that reconciliation cannot function to synergize with equity, revitalization, reveals, and reconstructions, however, it serves as a process and outcome; relationship-building and co-existence; political progress; forgiveness and justice; and a process of top-down and bottom-up. Regardless of the process, a reconciliation may have particular implications.

Of many violent incidents in Aceh Province that often happened frequently from 1989 to 2005, both big and small quantities of casualty, the murder is still viewed as a crime even done for the sake of the country. The well-known, violent incidents are the tragedy of Rumoh Geudong on August 20, 1998, Krueng Arakundoe on February 3, 1999, and Jambo Keupok on May 17, 2003. Until now, the victims of those tragedies have not received special attention from the Indonesian Government of which is scapegoated for these all miseries. A concrete step to initiate the effort of reconciliation seemed unrealistic to happen. After the conflict was over and MoU was signed, all the plans and ideas toward reconciliation were mysteriously faded. The reasons for apologizing are not enough; it requires a high level of sincerity especially for those who triggered the conflict.

Hitman (2020) suggests that independent variables - policy; the scale of policy's implementation; external occasions relevant to the protest party; and decision-making of party's leadership - might contribute to the condition. The collapse of the New Order in the regime of the second president of Indonesia, Soeharto, does not affect the typical repressive action done toward residents. It was proven from the series of violence done by state apparatus in several areas, for instance in the Aceh and Papua provinces. During the era of Megawati, humanitarian disasters worsened. Her regime established the status of 'martial law' under the Integrated Operation. The word 'integrated' refers to the involvement of not only a military component, but also a humanitarian program, law enforcement, and the local government (Husein, 2017).

The operation aimed to wipe out all of the rebellion movement. Both sides might trigger the no-war-no-peace situation, which should be redeemed by explicitly showing mutual trust as suggested by Andersson and Mukherhee (2021). Whether the military operation of the Indonesian Government was to concord the country's unity or the need to rule the province, the continuous views of the Acehnese post-war victims had. In reality, the value of the agreement was minimally felt for certain Acehnese people, mainly the victims.

Hydén (2000) discusses four relevant issues that lie in a war reconciliation - internal conflicts; nature and extent of divisiveness; policy intervention; and involvements of locals. The last-mentioned issue relates to the prospect for peace, democratization and reconciliation, which depend on the community's responses. Acehnese people, like other war victims in Bosnia, Guatemala, Kosovo, Palestine, Somalia, and others, believe that the peace accord brings 
no satisfaction to all warring parties. In addition, the range of armed frictions, tyranny and fragmentation under the strain of structured lawbreaking and turbulent tensions, either in the past or present, may turn into challenges for a reconciliation (Oettler \& Rettberg, 2019). Some cases of reconciliation may bring insights to learn. To illustrate, in the context of Indonesia, Malukans took the path of interdependence in their conflict of religion, where the formal institutions were absent, making the peace more viable (Kusumaningrum, 2017).

This traces the recent views of Acehnese people concerning to what extent reconciliation relieved them by associating their responses to the stages made before the peace agreement and its implication. This paper may add another knowledge of reconciliation in terms of violent incidents in a Muslim-based area.

\section{Methods}

This research used qualitative methods, which aim to understand a phenomenon in a social context naturally by prioritizing the process of deep communication interaction between researchers and the studied phenomenon (Herdiansyah, 2010). Therefore, the researchers used a descriptive analysis model that focused on describing and analyzing phenomena, events, social activities, attitudes, beliefs, perceptions, thoughts of individuals or in groups (Nana, 2007).

The sample in this research was selected by using a purposive sampling technique where educational, occupational and gender qualifications were taken into account. This consideration aims to produce representative research results. Therefore, the segmentation of prospective informants must be determined in advance, so that the data obtained can later represent the voice of the community.

In addition to the sources of data, the research employed the snowball-sampling technique to determine key informants after deciding the location and time of the research.
Then, through key informants, other key informants of the new groups' members could be found. In total, there were 16 direct victims (DV) and indirect victims (IV) were visited to share their arguments as detailed in Table 1. Here, the direct victims were people who became the victim of the abuse and the key informants while the indirect victims were people living nearby and witnessing the case of harassment. The challenge here was finding the direct victims in every place of evidence; the DV seemed not to want to expose their experience due to trauma. The witnesses from the officials as military and police were also unable to be interviewed since the cases were confidential and sensitive. The data in terms of books, media, documents, and newspaper clippings were also analyzed to provide theoretical power to the arguments that researchers will build in this study.

The data obtained in this study were analyzed using the grounded theory approach

Table 1.

Details of informants

\begin{tabular}{cccccc}
\hline No. & Initials & Age & Sex & Status & $\begin{array}{c}\text { Place of } \\
\text { Incident }\end{array}$ \\
\hline 1 & RK & 65 & Female & DV & \\
2 & SA & 61 & Female & DV & \\
3 & NA & 57 & Female & DV & $\begin{array}{c}\text { Rumoh } \\
\text { Geudong }\end{array}$ \\
& & & & & \\
4 & UH & 60 & Male & DV & \\
5 & TA & 76 & Male & DV & \\
\hline 6 & RH & 54 & Female & IV & \\
7 & MJ & 61 & Female & IV & \\
8 & ML & 60 & Female & DV & Krueng \\
& & & & & Arakundoe \\
9 & NJ & 58 & Female & IV & \\
10 & MK & 64 & Male & IV & \\
\hline 11 & HM & 37 & Female & DV & \\
12 & JA & 38 & Female & IV & \\
13 & YD & 40 & Female & IV & Jambo \\
& & & & & Keupok \\
14 & JH & 46 & Female & IV & \\
15 & MB & 51 & Female & IV & \\
16 & ZK & 55 & Female & IV & \\
\hline
\end{tabular}

Source: Informants from three mentioned places of evidence; Rumoh Geudong, Krueng Arakundo and Jambo Keupok. 
as proposed by Charmaz and Thornbeg (2021). This theory focused on the finding toward observed phenomenon as amplification of theories related to the case occurring within the area of study. Hence, the result of the study would portray the objective condition relating to the phenomenon studied.

\section{Results}

There have been many violent incidents that occurred in Aceh Province. Presently, none of these cases has been resolved legally according to the mandate of the Helsinki MoU as stated in sub-point 2.2 that a human rights court would be established to defend the victims of military harassment during the era of conflict. Many contradictions between the theoretical point stated in MoU and the factual condition, such as in the establishment of the human rights court; until today, there was no such court established in Aceh.

\section{Rumoh Geudong: A Tragedy Exploration}

Rumoh Geudong was just one of the biggest military camps in Aceh Province during the MOA period. Normatively, it was a traditional Acehnese house, which was then turned into a Pos Sattis (the Post of Tactical Units) of Tentara Nasional Indonesia (abbreviated as TNI, the National Armies of Indonesia) and Polisi Republik Indonesia (abbreviated as POLRI, the Indonesian Republic Police). Yet, practically, Rumoh Geudong became the camp for persecuting the Acehnese people. They were taken and treated beyond the humanitarian limits for the unity of Indonesia. In addition, men were taken arbitrarily for getting hurt and women got unlawful sexual activity where some of them were eliminated (Rahmani, 2021).

Some of the persecuting actions were beatings on the body, limbs and head using various tools like long wood, rattan, bottles, and iron bars. Other afflictions were snatching bodies with a vehicle chain, electric cables and stingray tails; getting an electric shock in various parts of the body, including the eyes and genitals. In addition, other agonies were being hanged with heads down while being hit; having sexual assault (genitals entered objects, women told to shave male genitals, pubic tongs pliers) and rape (Rahmani, 2021). The following quote portrayed the afflictions and harassment committed toward the victims.

I never expected that it would happen like this. I was forcibly taken from my home to Rumoh Geudong. A few weeks later, I was mistreated insistently. I was also pregnant at that time until they put the tip of their weapon into my genital. They terrorized me to reveal where my husband was, but I did not know where he was (RK).

I was disrobed, so was my husband. I witnessed that TNI made suffer on him by clipping a plier flowed electricity to his sexual organ and clipping it on my teats, and that was not all. Eventually, I was released, yet my husband still stayed there and became the target of violation. They should feel the pain of being shocked by the electricity on their sexual organs and suddenly talk about reconciliation. Should they be forgiven? (SA).

I was treated as if I committed a very chaotic mistake in this country, and they kept asking and forcing me to answer what they wanted. I got electrocuted, groped, and abused. I did not know what to do because there were many of them, treating everyone as they liked. Until today, I never felt the result of the peace (NA).

After the $2005 \mathrm{MoU}$, I could not take anything from the peace agreement. There was no recovery or restoration for both moral and formal aids. The politicians simply only wanted to talk without trying to actualize them 
truly. The peace was worth nothing if the efforts came for nothing (UH).

I never expected that I survived after the series of afflictions I experienced in that house. As I recall, the militaries were heartless, mistreating without showing mercy. My sexual organ got electrocuted many times and they smiled while doing it. The result of reconciliation might be tasted for the elite group only. How about us, the common people? What was the role of the government? Where was the peace? (TA).

Based on the avowal of the victims, most of them still did not accept the reality that there was no power of justice to punish the armies committing the violence within that house building. The violence indeed was reported in the Pro Justitia documents to the Komisi Nasional Hak Asasi Manusia (abbreviated as Komnas HAM, the National Commission of Human Rights). However, due to a large number of cases, approximately 3.504, the arrangement of which was sluggish, not to mention the factors of integrating political interest or paying the cautiousness upon the cases (Razali, 2019).

The interview also revealed the fact that most of them experienced Post-Traumatic Stress Disorder (PTSD). It was triggered by their experiences and amplified by the recent fact that there was no support for them and the court was done to bring justice toward the victims. It was in line with the study of Somasundaram and Sivayokan's (1994) work toward the victims of local conflict in Sri Lanka, which indicated that PTSD was the most common disorder caused by post-conflict trauma.

\section{Krueng Arakundoe: A Midnight Terror}

The Krueng Arakundoe tragedy was executed after the revocation of the status of
Aceh as MOA on August 7, 1998. With the revocation of DOM, people became the objects of the violence on behalf of the country. This tragedy happened on Wednesday, February 3, 1999, exactly in front of the Markas Komando Rayon Militer Idi Cut (abbreviated as Koramil, the Headquarters of Military Regional Command) and the local office of Kepolisian Sektor Idi Cut (abbreviated as Polsek, the Sectorial Police Office). The following are the excerpts conveyed by the library research in a report made by Ishak (2001).

On that day, there was rapid shooting toward people that stopped on their way home from the location of the meeting of preach with the preacher from Gerakan Aceh Merdeka (abbreviated as GAM, Free Aceh Movement) activist. The dead bodies were collected, put into an empty sack, carried by truck to the Arakundoe riverside, and later were thrown after being given the weight. This tragedy shocked everyone and gave the signal that MOA was back in Aceh. My brother became one of the dead victims of the tragedy. He left his wife and a child. For about 14 years of the peace agreement, our family did not get compensation and care from the government in any form for his heir (Ishak, 2001).

The statement in that study was supported by the data found during the interview as stated by the informants below.

Since being left by my husband who died by the TNI, I had to work extra to support my family. I expected that the government could help and accommodate all my needs and education for my children. I sometimes regret this life condition being ignored by the government. GAM activists now deliberately forget what they could do for their responsibility. I hated to be deceived in such conditions repeatedly $(\mathrm{RH})$. 
Until today, the death of my child seemed to be easily ignored, without any fair legal proceeding toward the victims and perpetrators. Now, everything is the same, those who claimed themselves as warriors had nothing to do with us, common people to fight for justice. (MJ).

I barely reckon if the independence of Indonesia existed. I also witnessed the life of other common people when they became the victims of politics. We had nothing to do with politics, so why have we always received all the impacts? The war became the proving peak where people became treated miserably. So after the war, without our efforts, we were dead already. There was no responsibility from the country toward me for the death of my child. (ML).

The end of the horrifying war would also never be easy for us. There was no help and support from the government. What we had fought, if their belly was already full, they would forget about us. Only when National Election Day came, the candidates promised 'heavens' to us. (NJ).

The apology was delivered simply during the ceremony, just like playing around. Fake war, but truly died, including my son. I wanted the government to send their apology personally and directly, adjudicate the perpetrators, both the soldiers and the generals involved in (MK).

Similar to the findings in the first location, the informants interviewed revealed that they would not forget the gloomy, gory moment. Yet, they just asked for one thoughtfulness, a sincere confession from the Indonesian Government accompanied with the deserved punishment for the offenders, as they also did not want the dead-end path found in seeking peace.

The role of investigation and the establishment toward the human rights violation done toward the process of peace and reconciliation was so obvious (Sooka, 2006). Yet, both were never established after the local conflict in Aceh. This case was shown by the interview that all victims were disappointed and felt that no justice for them. It just amplified the trauma among them and made the investigation even harder since they chose to be silent while interviewed by thirdparty researchers.

\section{Jambo Keupok: An Arrogant Sketch}

Jambo Keupok is a village located in South Aceh Regency and surrounded by mountains. With an area of two square kilometers, it has four hamlets - Keude Tuha, Hilir, Seuneubok Pareh, and Dusun Tengah. On Saturday morning, May 17, 2003, dozens of TNI from Para Komando (the Special Force Units) and Satuan Gabungan Intelijen (the Merger Intelligence Units) having military posts in the regency of Bakongan visited each resident's house. They stood guard at the front and back. A moment later, they entered the houses to check and force the occupants to leave, including old and young people. They were then collected into a place. A group of men was separated from women and children. They were placed in a house made of wood, and they were beaten up (Marzuki \& Warsidi, 2011). On that day, there had been afflictions, murders, and burnings toward sixteen villagers of Jambo Keupok done by the armies. Until today, this case was investigated by the Commission of National Human Rights of Indonesia and the investigated files were taken up to the Attorney's General Office (KontraS, 2016), yet none of the good news appears. The tragedy in the village was portrayed by the following informants. 
Many people were wearing a typical military uniform with a set of weapons, destroying our houses and neighbors'. All were forced to leave the houses rudely. Then we were locked up in the school building. A moment later, we just heard the gunfire. My father's dead body was also burned after getting a headshot along with the other eleven victims. Until today, my family and others never got any compensation from the government (HM).

It has been seventeen years since that tragedy, and no one came for us to give the compensation, even from the government. The more I expected, the more my heart hurt. All was the same, either GAM or central government. Although many former members of GAM are in governmental positions now, their roles meant nothing to us. They are liars (JA).

There is no one responsible for the murders that we had been through. Does this kind of law exist? After all this, only the Commission for Missing Persons and Victims of Violence, known as KontraS, always came to see us, giving help and aid. Yet, there was no help coming from the government or country that did this to us (YD).

My husband was innocent since he was not involved in GAM. I never expected that morning would be my last day to see him. Until now, people were busy talking about peace. Which peace do they mean? I never felt that even though it was declared in 2005 as reconciliation for conflict that happened in Aceh. There was no responsibility seriously or sincerely done by the government $(\mathrm{JH})$.

I hugged my young brother very tightly, but the soldiers kept taking him by force from my hug. They did a headshot on him and I saw it very clearly. They did it without guilt, were the soldiers educated? We were seen as individuals who did not deserve help after this war. There was no help and support. There was no responsibility at all from them $(\mathrm{MB})$.

They shot my husband on his head. My husband worked as a farmer, he had nothing to do with GAM. There was no responsibility from the government. Until today, I worked, as usual, earned a living for my children, for their education. There was no one came in for delivering help (ZK)

The findings obtained from the informants for the third location were almost the same as previous ones. Their voices were muted to transmit the truth to the outer world, specifically from the Indonesian Government. The armies had no intention to verify the civilians in the first place, not to mention to burn down all their properties.

\section{Discussion}

The rebellion of Aceh Province had been initiated by Daud Beureueh with his Indonesian Islamic Army. The movement was triggered by the mismatch of political promises made by the first president of Indonesia, Soekarno, at the start until the end of the turmoil (Darmanto, 2014). In contrast to the previous movement, Hasan Tiro, the governmental representative of GAM, used a more global echo in voicing the rights of Aceh Province, which had long been taken away by Indonesia. His movement was termed the Aceh Sumatra National Liberation Front (ASNLF) at first, and then it was changed several times until GAM became the last rebellion title.

The year 1976 was the beginning of Hasan Tiro's declaration of GAM, continuing the fights 
from the movement of Daud Beureueh. The history of the reason why Hasan Tiro wanted to fight Indonesia was that he considered that Indonesia under Soeharto's control had exploited the natural resources owned by Aceh Province very massively without giving any positive effect from this exploitation. In other words, Hasan Tiro carried out propaganda through the issue of colonialization of his nation and the history of glory of Aceh in the past to get sympathy and support of the people of Aceh to join the established organization to be more durable (Chaidar, 1999). His assumption relatively rejected the authority to govern his region as the Indonesian Government was first gifted to Aceh in 1959. The echoed jargon of decentralization initiated in 2001 was on the contrary since the inequalities in terms of economic development within the community ensued in the outer islands of Indonesia (Diprose, 2009). It was no wonder that the reform had a minimal contribution to developing regional areas of Indonesia (Hill \& Vidyattama, 2016).

The peak of the suffering felt by the Acehnese people in this rebellious war occurred from 1989 to the present. Positively, the successor of Soeharto, Bacharuddin Jusuf Habibi, pioneered a slight paradigm shift. However, the commander of Indonesian armed forces, General Wiranto, was trying to regain public trust by revoking the status of MOA in Aceh Province on August 7, 1998. In addition to the revocation of the MOA, both of them went to the province in March 1999 to apologize for the behavior of the security forces (Djumala, 2013). The violent methods used by the Indonesian government to crush GAM during the MOA period put the success of security operations into a big question since what happened was that the civilians became victims while GAM was getting bigger.

In May 2003 under the new president, Megawati, martial law was declared in Aceh Province. In this state of emergency, the civil administration was suspended and a massive operation to quell the rebellion was launched against the pro-independence armed group, GAM. It was the most violent year in the 28year conflict in the province. In May 2004, the status was downgraded to a civil emergency. Although indeed the Indonesian government was returned to the hands of the civilian authorities, military operations were still being carried out and human rights violations were still being reported (Siregar, 2016). Therefore, in chronological order, the MOA period in Aceh occurred for 9 years (1989-1998) and reported 128 rape cases. Then, a humanitarian break and cessation of hostilities took place from 1999 to 2003, followed by the status of Military Emergency (2004-2005), the status of Civil Emergency (2004-2005), the Helsinki MoU (August 15, 2005), and finally now the period of implementation of Islamic law.

As has been mentioned earlier, Acehnese women faced various violence, discrimination and restrictions related to policies that emerged during those periods. From May 19, 2003, to November 19, 2003, the First Military Emergency was imposed based on the Presidential Decree No. 28 of 2003. It was then extended to the Second Military Emergency from November 19, 2003, to November 19, 2004, based on the Presidential Decree No. 97 of 2003. Consequently, those decrees restricted civil liberties and made the Acehnese women vulnerable to human rights violations (Komnas Perempuan, 2009).

In the context of peacebuilding between Aceh Province and the Indonesian Government, the former became the illiberal peacemaker, while the latter was the liberal peacemaker. The condition after $2005 \mathrm{MoU}$ made a mediator of reconciliation pioneered by CMI centered on peace development to both governments. This focus considered the position of Aceh Province having the special regulations after the negotiation; thus, the province had greater autonomy to create peace based on the culture of its people. 
There was such a sustainable fallacy in the implementation of post-war reconciliation in Aceh Province. The return of rights supported by the mediator was the potential way for the province to rise from the ruins of destruction. Yet, the illiberal peacemaker did not take advantage of the opportunity that had been legalized to do the best in giving the best contribution for the people. As the result, nowadays, it can be observed many social cases occur due to incompetent ways in overcoming the reconciliation process after the local war in Aceh. One notable case was a rebel act committed by a former combatant of GAM, Din Minimi, in East Aceh (Utama, 2015). This act was triggered by the injustice and unfair threats done by the Government of Indonesia and the Government of Aceh in establishing the welfare of former combatants of GAM.

Similar cases have possibilities to occur due to the recent economic condition of Aceh. The public relation of the local government of Aceh still reported that the province was in the seventh rank of the poorest province in Indonesia (Biro Humas dan Protokol Pemerintah Aceh, 2020). Such a condition was a paradox considering Aceh was a province receiving Otonomi Khusus (Special Autonomy Status). As reported, Aceh had received IDR 56,67 trillion as a specific budget due to the Special Autonomy Status on this province since 2008 (Dani, 2018).

In terms of human rights, the post-war reconciliation had not yet overcome the issue of the victims. This was proven by many victims that were interviewed by the researchers that implied the desperateness toward the government. This was caused by the excess conflict that they experienced would never be comparable to what the government had given. In this case, indeed, the government did not care toward the victims, but their rights had never been fulfilled maximally.

Some victims experienced physical violence from the forces. They did not receive anything from the government either from the local or national one. The victims should be consoled through the help or at least be provided with certain workshops and training related to life skills. Furthermore, the victims, particularly women and children required special treatment to recover from the local conflict. Yet, their right to get psychological reparation was not fulfilled. Putri and Permatasari (2018) noted this case as the fulfillment of reparation right toward female victims of the Aceh conflict was not implemented under the international law of human rights. In this case, the rehabilitation merely focused on the providing of financial compensation. The need for psychological rehabilitation was urgent for the susceptible parties as women and children.

Ironically, many pieces of evidence committed were not only by TNI but also by GAM did violations toward them. Those authentic pieces of evidence could be the countless number of people that were defective and wounded due to the violence that had not been handled until today. Moreover, there were also many carelessly abandoned graves located in remote areas of the conflict.

Moreover, the shreds of location evidence where the violence occurred had long disappeared. After the war ended, people flocked to destroy the buildings due to overcoming trauma. For instance, Rumoh Geudong is now just the yard with a few lower parts of the walls remaining. Many graves were dug up to bury the people, either already dead or alive, both inside and outside of the building. Unfortunately, when people passed by the location, there was no evidence of the history of violence at Rumoh Geudong that could be witnessed since the evidence and remains of violence, the house itself had been burnt by the people and decayed by ages; despite a monument had been erected, the physical evidence, the house of Rumoh Geudong, had been burnt by the traumatized people. The building should be preserved 
and be kept as what was left by the soldiers; hence, all the evidence would remain factual and could convince the arguments for further discussion about the disclosure of the truth. This phenomenon also occurs around Krueng Arakundoe and Jambo Keupok. Fortunately, there was a monument built to remember the victims at the last-mentioned place, although it was built by local people, not the government. The community became another victim, who was being detached from the valid law enforcement, which possibly resulted in continuous trauma (Gittner, 2016).

When the reconciliation was declared, all parties - armies and governmental officials of GAM and Indonesia - were asked to tell the truth to gain certain interests from the compensation. This also involved the real and fake victims. Even the former members of GAM and the government kept providing the information emphasizing that what had been done by them was for the sake of national security. The statement on behalf of the country turned into their jargon when being asked about the tragedy of violence that happened in Aceh Province. Nevertheless, voices about the disclosure of truth and reconciliation must be forwarded. Yet, the factual disclosure and some concrete steps had not been realized until today. When the war was over, the guilty ones did not want to beguile and kept roaring to hide their faults. This notion was reflected by the victims' statements, as in the interview part. Moreover, the majority of victims were female; female victims were more fragile than males as they required more post-traumatic support and healing (Connolly, 2012). Hence, the process to achieve the social truth still did not perform a development.

Still, all this time, the victims of the conflict in Aceh Province did self-reconciliation and should fight for the healing of all wounds. If either minimal or maximal reconciliation is implemented, the reconciliation context for Aceh Province is still vague, after either minimal or maximal reconciliation is implemented. However, the authorities always said that "We are fighting for it". Fourteen years ahead, after the signing of the MoU, the matter of reconciliation was still in discussion. The struggle that was stagnant toward a possible reconciliation was caused by the actors who did not want a confession, admission, and apologies. Such conditions stashed a potential further conflict as they kept the trauma themselves and might result in insurgencies in the future (Brounéus, 2007).

Society truly understood the past events to establish the responsibility and to refuse the impunity continuously; surely, the truth could not simply reconcile the ex-enemies. The surviving victims in Aceh Province need more ears to listen. They looked for the improvement of justice for the guilt. Besides, they looked for the guarantee that they would be protected in the future.

Indeed, it looked difficult for the Indonesian Government to admit what they have done in the past toward Aceh Province, specifically the violation of human rights committed by the army military units. This case emerged when a commitment to clean up the history started to sound on. The voices of victims that had been muted for a long time should be resounded, so the Indonesian Government could reform the institutions involved as the agent of violence. However, whatever the reasons, this path was essential for a potion, confession, and reconciliation.

The confession toward the victims would be based on the model of dialogic interaction. An individual saw one another as the equally respected creatures in reciprocal. A human becomes a complete individual through confession and admission, which emphasizes the identity formation of inter-subjectivity. Many works of literature describing confession assert that it needs an ethical condition of complete self-realization from society (Taylor, 1994). Therefore, the confession upon 
the victims should cover the material and symbolic components to secure the status of equality. Related to the symbolic confession, the confession must highlight the omission of cultural views that prevent the individual to recognize one another as the same people to reach what is called the inter-subjectivity condition of participation parity (Fraser \& Honneth, 2003).

Reconciliation as the sense of respect is to respect tolerance and to carry the peace of political contestation would never develop when the past was examined truthfully or when horrifying violence was not justified. An honest and sincere understanding of the past was necessarily morally needed, even though this thing could hurt the victims and unsettle them who were pros with the perpetrators. Accountability is also needed for impunity culture, language superiority, and humiliation that were deep for the rights of individuals. Thus, the importance of admitting and confessing the victims as citizens has an equal moral for all people.

However, after a long period and distance between the war and the agreement of not being involved in the war, every victim requested the Indonesian Government to confess. Principally, victims asking requests for remedying their wounds were awkward considering their status as the victims. They should be treated at the very first time. Hence, those unnecessary, undelivered requests are deserved to have access by the Indonesian Government because it might become the commencement of framing the reconciliation process.

Healing the past wounds that had been long ignored would never be handled only with the psychological and physical treatment by presenting doctors and medical practitioners. There was a wound that could be healed by the treatment of honest confession, and that was an exceptional elixir for certain post-war events in every country, including Aceh Province. The confession from the conflict perpetrators - the
Indonesian Government and GAM - would share the priceless value of kindness.

Reconciliation is meant to restore, although it could not be fixed just like before. As the main responsible element for its people, the government at least must try an effort of reconciliation through its confession, revealing the truth and begging for forgiveness to them. This is an unpretentious request but influential toward the condition post-war in Aceh Province or other countries' conflicts. Admitting and confessing the gloomy history would generate the frame of reconciliation gradually as if a shadow had a real face. Reconciliation becomes the peace path to break the chain of conflict in the post-conflict era. It is not to overlook the past, but to convert the heart-rending experience into forgiveness.

Sujatmiko (2012) noted the complex condition of Aceh due to reconciliation after the local conflict. At least, three parties' interests were intertwined in this process. The first was the former combatants of GAM, who urged politico-economic redistribution. Then, the Islamic community demanded the implementation of sharia. The last was the government of Indonesia, which was determined to preserve the territory. Since 2009, many policies and efforts had been taken to accommodate their interests: the implementation of sharia in Aceh, Special Autonomy Status, and the establishment of Undang-undang Pemerintahan Aceh (Aceh Governing Law) as the foundation of shared authority between the local government of Aceh and the government of Indonesia. However, with regret, the policies had triggered more complex issues. As Manan and Ismail (2014) reported, several points in the sharia implemented in Aceh were unfair for women. The establishment of Aceh Governing Law also left problems for Aceh. The case of the local flag, as a point in that law, remained a problem, even after 15 years of peace reconciliation in Aceh (Maharani, 2020). 
The existing problems around the process of reconciliation in Aceh left the urgent issues untouched. The physiological condition of victims remains neglected by the governments, both the local government and the Indonesian government. The uncertain condition of Aceh's political atmosphere, as well as security, still became challenges in providing mental health care for victims of war in this area (Marthoenis et al., 2016). In addition to this notion, many areas in Acehnese life were still uncertain. Such a condition quickly becomes a challenge for every related party in Aceh.

One notable party in Aceh is the Islamic scholars. The role of contemporary Islamic scholars (Ulama) within the reconciliation process in Aceh was noted by Sahlan et al. 2019). This party had a great role due to the people's reliance on them. It was in line with Omerovic's (2017) study that reported the Imams, as religious leaders, had a role as relationship-builders among parties relating to the conflict. Hence, the ulama have to be more actively involved in the reconciliation process in Aceh. Their role in socio-religio-cultural aspects cannot be denied as the people of Aceh put them in a special position among societies; their words are references in all aspects of life of Acehnese people.

The role of religious values within the post-conflict resolution was undoubtedly significant. The religious values offered discussion and peace in a resolution of conflict (Sewe, 2018). In the case of local conflict in Aceh, religion had potency as a peacemaker solution. As known, Aceh had implemented Sharia for a long time. This implementation actually might be a facilitator for peacemaking. Furthermore, the role of Islamic traditional educational institutions called dayah can be optimized toward the reconciliation of conflict. The value of sincerity, which was a value in the Islamic tenet, was a key value in dealing with post-conflict trauma. Here, the role of that institution was to educate people about sincerity; they had to have peace with the past. Thus, the role of such an institution was important (Harpviken \& Røislien, 2005).

The local conflict in Aceh had been going on for a long period. It generated trauma and tears from the Acehnese people since the decade of 70s. The peace of Aceh along with the existence of Helsinki MoU were dreams come true for the people of Aceh; even though both were triggered by the terrible disaster of the Tsunami in 2004. However, the peace was still in the beginning phase as many problems and challenges still confronted the recent condition. Here, the goodwill of the Indonesian government in a consort of the will of local government was the key for peacekeeping in Aceh. Moreover, the communities' participation and the role of religious tenet in Aceh were also significant during the time of reconciliation and the reintegration of Aceh.

\section{Conclusion}

Post-war victims in Aceh Province slowly begin to realize that they would continue to be victims. There is no peace between them in the 'marriage contract' between GAM and the Indonesian Government. When they quarrel and flare up, it is the beginning of innocent humans becoming victims. However, when the two of them are married, they promise to live together in goodness, both joy and sorrow, nor does it change the status of the victims. Indeed, there is peace, but it is only limited to those who declare it. The peace does not reach the community members who are swallowed up by violence.

Those who are disappointed then come with certainty, it turns out that it is a shadow of unreal peace. The disappointment is irreplaceable but sits down and unites with the previous disappointment. They struggle to unite to create new sadness in a new era. Peace is not a simple thing, and it is not achieved and will never be achieved by simple means either. Obstacles and obstacles are a unity that will be 
faced for peace. The price of peace will not be paid simply by improving the present to shape the future. Past destruction is a priority that must be fixed to be able to repair the present and then create the future.

\section{References}

Andersson, T., \& Mukherjee, C. (2021). Seeking no war, achieving No peace: the conflict over the Siachen Glacier. Defence and Peace Economics, 32(3), 253-270. https://doi.org/ 10.1080/10242694.2019.1660839

Biro Humas dan Protokol Pemerintah Aceh. (2020). Aceh peringkat 7 nasional penurunan angka kemiskinan. http://humas.acehprov. go.id/aceh-peringkat-7-nasionalpenurunan-angka-kemiskinan/

Bloomfield, D. (2006). On good terms: clarifying reconciliation.http://edoc.vifapol.de/opus/ volltexte/2011/2521/pdf/br14e.pdf

Brounéus, K. (2007). Dialogue on globalization: reconciliation and development. Friedrich Ebert Stiftung.

Charmaz, K., \& Thornberg, R. (2021). The pursuit of quality in grounded theory. Qualitative Research in Psychology, 18(3), 305-327. https://doi.org/10.1080/1478088 7.2020 .1780357

Connolly, L. (2012). Justice and peace building in post-conflict situations. ACCORD Occasional Paper, 6(1), 1-38.

Chaidar, Al. (1999). Gerakan Aceh Merdeka: Jihad Rakyat Aceh Mewujudkan Negara Islam. Cibinong. Madani Press.

Dani, S. (2018). Ini total dana otsus yang telah diterima Aceh sejaktahun 2008. Serambinews. https://aceh.tribunnews.com/2018/07/08/ ini-total-dana-otsus-yang-telah-diterimaaceh-sejak-tahun-2008

Darmanto, H. A. (2014). Pemberontakan Daud Beureueh (DI/TII Aceh) tahun 1953-1962. Jember.

Diprose, R. (2009). Decentralization, horizontal inequalities and conflict management in Indonesia.
Ethnopolitics, 8(1), 107-134. https://doi. org/10.1080/17449050902738804

Djumala, D. (2013). Soft power untuk Aceh. Gramedia Pustaka Utama.

Doxtader, E. (2003). Reconciliation $-a$ rhetorical concept/ion. Quarterly Journal of Speech, 89(4), 267-292. https://doi. org/10.1080/0033563032000160954

Fraser, N., \& Honneth, A. (2003). Redistribution or recognition?: a political-philosophical exchange (J. Golb, J. Ingram, \& C. Wilke (trans.)). Verso.

Gittner, L. (2016). Law enforcement disconnect from the community. Cogent Social Sciences, 2(1), 1-9. https://doi.org/10.108 0/23311886.2016.1191322

Harpviken, K. B., \& Røislien, H. E. (2005). Mapping the terrain: the role of religion in peacemaking.

Herdiansyah, H. (2010). Metodologi penelitian kualitatif untuk ilmu-ilmu sosial. Salemba Humanika.

Hill, H., \& Vidyattama, Y. (2016). Regional development dynamics in Indonesia before and after the 'big bang' decentralization. The Singapore Economic Review, 61(2), 1-26. https://doi.org/10.1142/ S0217590816400270

Hitman, G. (2020). From separatism to violence: a typology of interactions between the citizen and the state establishment. Cogent Social Sciences, 6(1), 1-13. https://doi.org/ 10.1080/23311886.2020.1832345

Husein, A. (2017). Catatan kekerasan HAM pada zaman Megawati berkuasa. Tirto. https:// tirto.id/catatan-kekerasan-ham-padazaman-megawati-berkuasa-cwbD

Hydén, G. (2000). Post-war reconciliation and democratization: concepts, goals and lessons learnt. In After War: Reconciliation and Democratization in Divided Societies Lessons learned. https://open.cmi.no/cmixmlui/bitstream/handle/11250/2436145/ WP2000.8 Goran-07202007_2. pdf? sequence $=2$ 
Ishak, O. S. (2001). Peristiwa Idi Cut Aceh : dari tragedi ke impunitas (1st ed.). Cordova.

Komnas Perempuan. (2009). Kondisi tahanan perempuan di Nanggroe Aceh Darussalam. Komisi Nasional Anti Kekerasan Terhadap Perempuan.

KontraS. (2016). Peringatan 13 tahun peristiwa Jambo Keupok - Merawat ingatan, menuntut keadilan. KontraS. http:// kontras.org/backup/home/index. php? module=pers\&id=2276

Kusumaningrum, D. (2017). Interdependence versus truth and justice: lessons from reconciliation processes in Maluku. Jurnal Ilmu Sosial Dan Ilmu Politik, 20(1), 34. https://doi.org/10.22146/jsp.17998

Lewin, E. (2016). The inevitable dead end of the Arab-Israeli conflict. Cogent Social Sciences, 2(1), 127-137. https://doi.org/10.1080/233 11886.2016.1227294

Maharani, E. (2020). 15 tahun perdamaian Aceh, bendera bulan bintang dikibarkan. Republika. https://www.republika.co.id/ berita/qf3ktf335/15-tahun-perdamaianaceh-bendera-bulan-bintang-dikibarkan

Manan, A., \& Ismail, F. (2014). Syari'at Islam di Aceh: realitas dan respon masyarakat. ArRaniry Press.

Marthoenis, M., Yessi, S., Aichberger, M. C., \& Schouler-Ocak, M. (2016). Mental health in Aceh - Indonesia: a decade after the devastating tsunami 2004. Asian Journal of Psychiatry, 19, 59-65. https://doi. org/10.1016/j.ajp.2016.01.002

Marzuki, N., \& Warsidi, A. (2011). Fakta bicara: mengungkap pelanggaran HAM di Aceh 1989-2005. Koalisi NGO HAM Aceh.

Nana, S. S. (2007). Metode penelitian pendidikan. Remaja Rosdakarya.

Nussio, E., Rettberg, A., \& Ugarriza, J. E. (2015). Victims, nonvictims and their opinions on transitional justice: findings from the Colombian case. International Journal of Transitional Justice, 9(2), 336-354. https:// doi.org/10.1093/ijtj/ijv006
Oettler, A., \& Rettberg, A. (2019). Varieties of reconciliation in violent contexts: lessons from Colombia. Peacebuilding, 7(3), 329352. https://doi.org/10.1080/21647259.20 19.1617029

Omerovic, N. (2017). The role of religious leaders in the process of reconciliation in Bosnia and Herzegovina: the case of Bosnian imams. Ibn Haldun University Alliance of Civilizations Institute.

Putri, L. H., \& Permatasari, M. (2018). Implementasi pemenuhan hak atas reparasi bagi perempuan korban konflik Aceh ditinjau dari hukum internasional. Syiah Kuala Law Journal, 2(3), 419-438. https://doi.org/10.24815/sklj.v2i3.12400

Rahmani, A. F. (2021). Bibilografi Sejarah Pandemi Black Death di Mesir Pada Abad Ke 14 M. Khazanah Pendidikan Islam, 3(1), 1-9.

Razali, H. (2019). Menunggu dewi keadilan mampir ke Rumoh Geudong. Lokadata. https:// lokadata.id/artikel/menunggu-dewikeadilan-mampir-ke-rumoh-geudong

Sahlan, M., Fajarni, S., Ikramatoun, S., Kamil, A. I., \& Ilham, I. (2019). The roles of ulama in the process of post-conflict reconciliation in Aceh. Society, 7(2), 251-267. https://doi. org/10.33019/society.v7i2.106

Sewe, M. L. J. (2018). The contribution of religion to social reconciliation: a case study of Liberia. Journal of Global Peace and Conflict, 6(2), 1-8. https://doi.org/10.15640/ jgpc.v6n2a1

Siregar, S. N. (2016). Pergeseran masalah keamanan di Aceh. Jurnal Penelitian Politik, 9(2), 51-62. https://doi.org/https:// doi.org/10.14203/jpp.v9i2.230

Somasundaram, D. J., \& Sivayokan, S. (1994). War trauma in a civilian population. British Journal of Psychiatry, 165(4), 524527. https://doi.org/10.1192/bjp.165.4.524

Sooka, Y. (2006). Dealing with the past and transitional justice: building peace through accountability. International Review of the 
Red Cross, 88(862), 311-325. https://doi. org/10.1017/S1816383106000543

Sujatmiko, I. G. (2012). Conflict transformation and social reconciliation: the case of Aceh, Indonesia. Asian Social Science, 8(2), 104111. https://doi.org/10.5539/ass.v8n2p104 Taylor, C. (1994). Multiculturalism: examining the politics of recognition. Princeton University Press.
Utama, A. (2015). Kisah negosiator Finlandia penghubung kepala BIN-Din Minimi. CNN Indonesia. https://www.cnnindonesia. com/nasional/20151231091159-20-101329/ kisah-negosiator-finlandia-penghubungkepala-bin-din-minimi 